\title{
El uso de la documentación en programas informativos no diarios: EI caso de Informe Semanal
}

\author{
Iris LÓPEZ DE SOLÍS \\ Documentalista de los SS. II. de TVE. \\ iris.lopez@rtve.es
}

Recibido: 04/04/2011

Aceptado: 10/05/2011

\section{RESUMEN}

El presente artículo analiza el uso de la documentación audiovisual en el programa informativo no diario más longevo de TVE, Informe Semanal. Para ello se ha tomado una muestra de cuatro meses de emisiones de este programa y se han establecido diversas categorías de imágenes tomando en consideración además su fecha de grabación. Junto a este estudio cuantitativo se ha profundizado en diversos aspectos: la reutilización del programa de sus propias imágenes, la inclusión de imágenes procedentes de otros programas informativos (diarios y no diarios) así como el uso de los "documentos especiales": imágenes de videoaficionado, fotografías y secuencias de documentales y películas. En concreto, en este último caso, la autora destaca un uso novedoso al que ha denominado "imágenes ficticias"; el uso de secuencias de películas para ilustrar hechos reales.

Palabras clave: Documentación audiovisual, televisión, programas informativos no diarios, reportajes

\section{The use of documentation in non-daily news program: Informe Semanal}

\begin{abstract}
The article analyzes how audiovisual documentation has been used in the oldest non-daily TVE news program, still on screen nowadays, Informe Semanal. Due to achieve this aim, a sample of broadcasting (four months) has been selected and the materials used on the production of the program has been divided into different categories, taking into account the original date of its filming. Beside this quantitative study, other aspects have been studied: The reuse in different programs of the same shooting, the use of materials from other news program (both daily and non daily), and the use of "special documents" (amateur shooting, photographs and films and documentary scenes). Specifically in this latter point, I have emphasized an original new use I have called "fictitious filming", referring to the use of fiction films due to enlighten real facts.
\end{abstract}

Key words: Audiovisual documentation, television, Non daily news programs, TV reports 


\section{INTRODUCCIÓN}

El sábado 31 de marzo de $1973^{1}$, tras el Telediario de la noche, aparecía en las pantallas un nuevo programa; Semanal informativo. Su fundador, el periodista Pedro Erquicia, tomó como modelo el programa estrella de la cadena estadounidense 60 minutes $^{2}$ A finales de 1973, el programa pasó a llamarse Informe Semanal y durante esos primeros años se convirtió en una interesante plataforma reivindicativ de diversos problemas sociales, como los derechos de la mujer ${ }^{3}$. Además, lidió constantemente con la censura, recurriendo a diferentes trucos, como distraer al censor durante el visionado del reportaje. Hoy, Informe Semanal se ha convertido en el programa informativo no diario más longevo de la televisión en España, y sus reportajes son sinónimo de calidad y seriedad informativa. El presente trabajo tiene como objetivo el estudio del uso de la documentación audiovisual en dicho programa, siguiendo la línea de investigación que Teresa Agirreazaldegi ${ }^{4}$ desarrolló en su tesis sobre el uso de la documentación audiovisual en programas informativos diarios en televisión y en la que estableció tres categorías de esos usos. En este artículo, se ha partido de dicha clasificación pero también se han añadido nuevas categorías según la fecha de grabación de las imágenes para distinguir y cuantificar lo que hemos denominado "imágenes recientes" frente a "imágenes lejanas", que serán aquellas grabadas hace más de diez años, para valorar el uso de imágenes de archivo según su fecha de grabación.

\section{METODOLOGÍA}

Para el presente estudio ${ }^{5}$ se ha seleccionado una muestra de 15 programas emitidos entre el 3 de enero y el 25 de abril del 2009. En 13 de los programas seleccionados se emitieron 4 reportajes por programa. En los programas emitidos el 28 de febrero de 2009 (programa 9) y el del 7 de marzo de 2009 (programa 10) se emitieron 3 reportajes por programa debido a la inclusión de un reportaje de mayor duración. En total, la muestra la forman 58 reportajes. Cada uno de los reportajes han sido visionado y

\footnotetext{
${ }^{1}$ El presente artículo es fruto del trabajo de investigación de doctorado dirigido por Elena de la Cuadra Colmenares y Félix del Valle. profesores de la Universidad Complutense, a los que agradezco su dedicación y consejos. Dicho trabajo es el punto de partida de la tesis que actualmente estoy realizando sobre el uso de la documentación audiovisual en programas informativos no diarios de TVE.

${ }^{2}$ Para profundizar en la historia de Informe Semanal: MAGRO, Baltasar. Informe Semanal. 30 años. Barcelona, Plaza y Janés, 2003.

${ }^{3}$ PHILIPPE, Virginie. Transition et televisión en Espagne. Le rôle de la TVE. 1973-1978. París, L'Harmattan, 2007.

${ }^{4}$ AGIRREAZALDEGI BERRIOZABAL, Teresa. El uso de la Documentación audiovisual en los programas informativos diarios. Bilbao, Universidad del País Vasco, 1996.

${ }_{5}^{5}$ Para el desarrollo de esta investigación he podido contar con la inestimable colaboración de Alicia Gómez Montano, directora de Informe Semanal, Jose Otero Roth, Subdirector de programas informativos de TVE, Paloma Hidalgo Goyanes, jefa de la unidad de análisis Documental de los SS.II. de TVE, Luis López Polinio, jefe de la unidad de atención a usuarios de los SS. II. De TVE y Manuel Aguilar, responsable de la unidad de atención a usuarios.
} 
minutado, teniendo como referente los registros realizados por el documentalista del programa ${ }^{6}$. Posteriormente, los reportajes se han clasificado en dos tipologías según el área al que pertenecen y a su relación con la actualidad.

Para la primera clasificación hemos determinado los siguientes campos temáticos que coinciden con las áreas existentes en los informativos, tal y como señala Rafael Díaz Arias ${ }^{7}$ :

- Política o nacional: Se trata del área más potente en los informativos, compartiendo en algunos casos temas con internacional en lo referente a política exterior y con economía en las noticias relacionadas con la información de la Unión Europea.

- Economía: En la mayor parte de los casos se refiere a la política económica del gobierno o a las críticas de la oposición a la misma. Abarca la información sobre macroeconomía, microeconomía y política económica y sectores.

- Sociedad: Su perfil es el menos definido de todas las áreas informativas ya que en ella tienen cabida desde el consumo a la educación, pasando por los sucesos.

- Cultura: Se centra en las manifestaciones externas de la cultura.

- Internacional: Actualmente, se ha reducido a la política nacional de los países extranjeros, la diplomacia y los conflictos internacionales. La información de la Unión Europea se comparte entre nacional, economía e internacional.

- Deportes: Suele centrarse en los deportes mayoritarios y de entre ellos el fútbol.

La segunda clasificación hace referencia a la relación del reportaje con la actualidad. Para ello se ha tenido en cuenta las aportaciones de Jaime Barroso ${ }^{8}$ y se han incluido además dos categorías basadas en aquellos temas o acontecimientos que el programa considera que deben ser recordados y en aquellas personalidades a las que se les dedica un reportaje centrado en su labor profesional o su vida personal. De esta forma, se ha considerado que la siguiente clasificación cubre todos los reportajes de la muestra;

- Reportajes ligados a la actualidad inmediata: Surgen por las noticias del momento. El reportaje profundiza en dicha noticia o en algún aspecto de ella.

- Reportajes ligados a la actualidad próxima o cercana: Surgen por noticias acaecidas en un pasado cercano y cuyas consecuencias siguen estando de actualidad.

\footnotetext{
${ }^{6}$ Para profundizar en el tratamiento documental del material originado por el programa entrevisté a Gracia García de Lomana, responsable de análisis de los programas informativos no diarios de TVE, y a Raúl Rodríguez, documentalista de Informe Semanal, a los que agradezco su disponibilidad y toda la información facilitada.

${ }^{7}$ DIAZ ARIAS, Rafael. Periodismo en televisión. Barcelona, Editorial Bosch, 2006, pp. 247-256.

${ }^{8}$ BARROSO GARCÍA, Jaime. "Reportajes y nueva televisión. No hay sitio, ni tiempo, ni dinero" Caleidoscopio. Valencia, Universidad Cardenal Herrera CEU, nº 5, 2002, pp.9.
} 
- Reportajes ligados a la actualidad permanente: Son temas que no están sometidos a la estricta urgencia de la noticia o crónica. Es decir, no están relacionados con sucesos o acontecimientos recientemente ocurridos.

- Reportajes biográficos: Se centran en la figura de una personalidad que es noticia por algún acontecimiento de la actualidad inmediata; nacimiento, fallecimiento, nombramiento de un cargo, concesión de un premio...

- Reportajes de efemérides: Reportajes conmemorativos o recordatorios de algún acontecimiento histórico.

En el estudio también se ha analizado el uso de los documentos denominados "documentos especiales" en los que se han incluido fotografías, vídeos domésticos y secuencias de películas.

Como ya he indicado anteriormente, el minutado de dichas imágenes se ha realizado teniendo en cuenta el elaborado anteriormente por el documentalista del programa y también se ha consultado el registro de GMS (Gestión de Material Sensible) para identificar todos los brutos grabados para el reportaje.

Se ha optado por no incluir en el estudio las imágenes que hemos denominado “imágenes de producción”; aquellas grabadas durante el periodo de producción del reportaje y que suelen proceder de los rodajes de informativos, de señales institucionales, de pools, de agencias nacionales o internacionales o del intercambio con otras televisiones (Eurovisión o FORTA). Para diferenciar estas imágenes, se ha establecido un límite aproximado de dos semanas anteriores a la emisión del reportaje. Sin embargo, en los reportajes elaborados por los corresponsales detectar dichas imágenes de producción ha sido más complejo ya que al Departamento de los Servicios Informativos de Torrespaña sólo suele llegar el premontaje, quedándose los brutos en la corresponsalía. Para diferenciar entre aquellas imágenes grabadas por el corresponsal, de las "imágenes de producción" y de las de archivo se ha procedido a:

- Valorar con atención el off de cada uno de los reportajes por si aportaban información sobre la datación de las imágenes.

- Localizar en prensa la fecha de los acontecimientos a los que hace referencia la imagen y el off. Para ello se ha consultado la base de datos de prensa BASINFA de TVE y su hemeroteca digital, ambas accesibles a través de la Intranet de la Corporación.

Respecto a la clasificación de las imágenes de los reportajes, se han establecido seis categorías en las que se han tenido en cuenta las aportaciones que Begoña García Nebrada, Juan Menor Sendra y Albert Perales ${ }^{9}$ presentaron en Telediarios y producción de la realidad y las que Teresa Agirreazaldegi incluyó en su tesis sobre la

\footnotetext{
${ }^{9}$ GARCIA NEBRADA, Begoña, MENOR SENDRA, Juan y PERALES ALBERT, Alejandro, VIDAL. Telediarios y producción de la realidad. Madrid, RTVE, 1985, pp. 54-65
} 
documentación en programas informativos diarios ${ }^{10}$. También, se ha incluido una diferenciación según la fecha de grabación de las imágenes para poder cuantificar el porcentaje de imágenes grabadas hace diez o más años. Por tanto, las imágenes objeto del estudio se han clasificado en las siguientes categorías:

- Imágenes noticia recientes: Se hace referencia a ciertos acontecimientos ocurridos hace menos de diez años de los cuales se ofrecen las imágenes.

- Imágenes metonímicas recientes: Son aquellas imágenes de hace menos de diez años en las que se presenta a los actantes fuera del contexto de la noticia o de la situación o momento a la que se hace referencia.

- Imágenes ambientales recientes: Imágenes grabadas hace menos de diez años que son utilizadas en un contexto más amplio para el que fueron grabados.

- Imágenes noticia lejanas: Se hace referencia a ciertos acontecimientos pasados de hace diez o más años de los cuales se ofrecen las imágenes.

- Imágenes metonímicas lejanas: Son aquellas imágenes de hace diez o más años en las que se presenta a los actantes fuera del contexto de la noticia o de la situación o momento a la que se hace referencia

- Imágenes ambientales lejanas: Son imágenes de hace diez o más años y que son utilizadas en un contexto más amplio para el que fueron grabadas.

Para determinar la inclusión de una imagen en una u otra categoría se ha valorado la relación entre la imagen y el sonido (en este caso, entre el off o las declaraciones y las imágenes incluidas en el reportaje). Posteriormente, se ha procedido a elaborar los distintos porcentajes para cuantificar:

- Uso de imágenes de documentación en la muestra seleccionada.

- Uso de imágenes de archivo recientes y lejanas en la muestra seleccionada.

- Uso de imágenes noticia, metonímicas y ambientales (recientes y lejanas) en la muestra seleccionada.

- Uso de imágenes de documentación en cada reportaje.

- Uso de imágenes noticia, metonímicas y ambientales (recientes y lejanas) en cada reportaje.

- Uso de imágenes de documentación en reportajes de economía, sociedad, internacional, nacional, cultura y deportes. Uso en cada uno de ellos de imágenes noticia, metonímicas y ambientales.

- Uso de imágenes de documentación en reportajes de actualidad inmediata, próxima y permanente y en los reportajes biográficos y de efemérides. Uso en cada uno de ellos de imágenes noticia, metonímicas y ambientales.

${ }^{10}$ AgIRREAZALDEGI BERRIOZABAL, Teresa. El uso de la Documentación Audiovisual en los programas informativos diarios. Bilbao, Universidad del País Vasco, 1996, pp. 40. 
Además, se ha procedido a realizar un estudio de las siguientes cuestiones;

- Reutilización por parte del programa de sus propias imágenes.

- Utilización de documentos especiales (fotografías, secuencias de películas y documentales e imágenes de videoaficionados).

- Utilización de otro tipo de imágenes procedentes de programas no informativos, de emisiones de programas informativos diarios, de otros programas informativos no diarios o de otras cadenas de televisión.

- Rotulación de las imágenes de archivo.

\section{Estudio cuantitativo de las imágenes de archivo}

La lectura de los datos obtenidos nos permite extraer unas primeras conclusiones sobre el uso de imágenes de documentación en Informe Semanal:

- En los 15 programas estudiados se han utilizado imágenes de archivo.

- De los 58 reportajes de la muestra de estudio, 43 han utilizado imágenes de documentación (un 74\%).

- En estos 58 reportajes se ha utilizado entre un $18 \%$ y un $19 \%$ de imágenes de archivo, de las cuales más de un 13\% son imágenes recientes y alrededor de un $5 \%$ son imágenes lejanas.

- En la muestra seleccionada predominan las imágenes noticia (6\% de imágenes noticia recientes y un $4 \%$ de imágenes noticia lejanas), seguidas de las imágenes metonímicas recientes $(4 \%)$ y de las metonímicas lejanas (4\%). El uso de imágenes ambientales recientes y lejanas es escaso (2\%). 


\section{USO IMÁGENES DOCUMENTACIÓN}

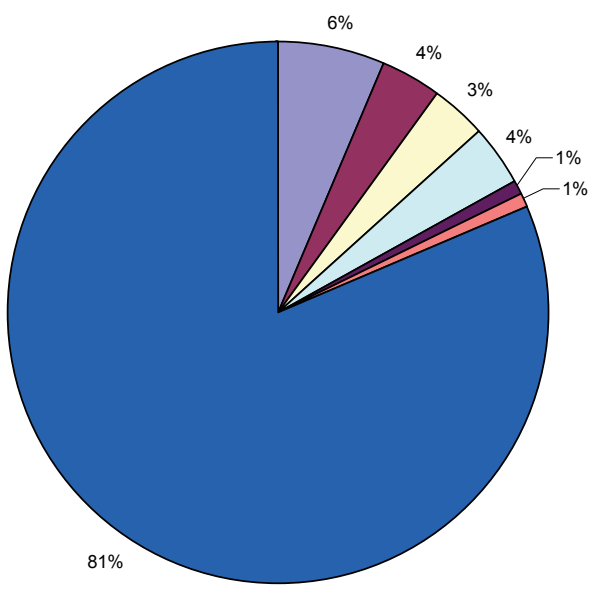

Imágenes noticia recientes

$\square$ Imágenes metonímicas recientes

口 Imágenes ambientales recientes

$\square$ Imágenes noticia lejanas

口Imágenes metonímicas lejanas

$\square$ Imágenes ambientales lejanashistóricas

口Imágenes de producción y grabaciones propias

\section{USO IMÁGENES RECIENTES Y LEJANAS}

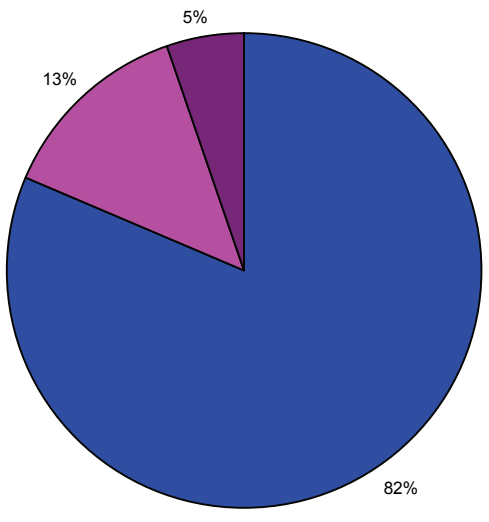


De los 58 reportajes, 7 han sido clasificados como biográficos, perteneciendo 5 de ellos al área de cultura y 2 al área de economía. En estos 7 reportajes se ha utilizado alrededor de un $32 \%$ de imágenes de documentación. Predominan las imágenes recientes $(18 \%)$ frente a las imágenes lejanas (14\%) y son también mayoritarias las imágenes metonímicas y noticias. Así, de imágenes metonímicas recientes se ha utilizado un $8 \%$ y de imágenes noticia recientes un 7\%. Respecto a las imágenes noticia lejanas nos encontramos con un 7\%, al igual que imágenes metonímicas lejanas. Sin embargo, el uso de imágenes ambientales es muy inferior (alrededor del 3\% imágenes ambientales recientes y $0 \%$ de imágenes ambientales lejanas).

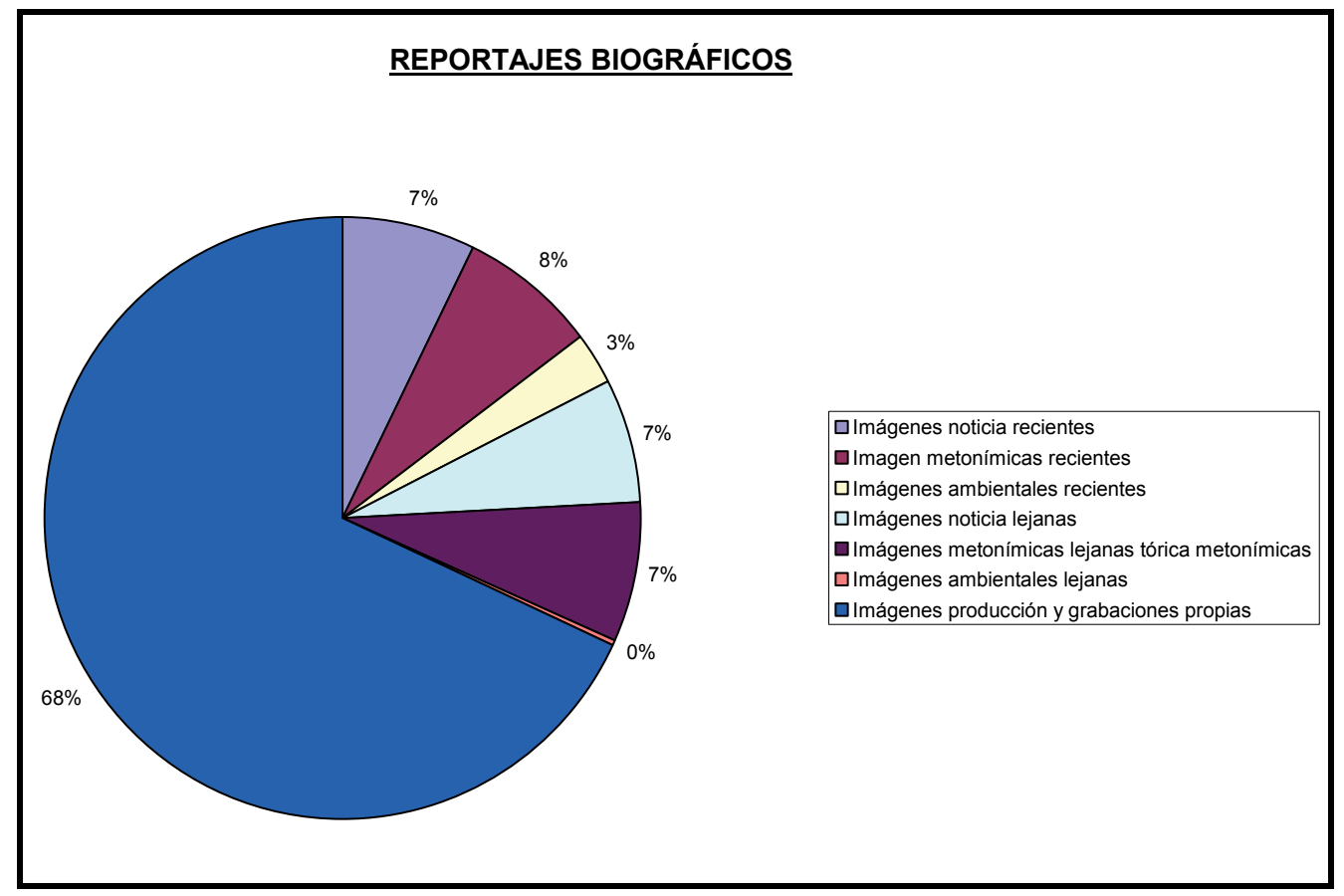




\section{REPORTAJES DE EFEMÉRIDES}

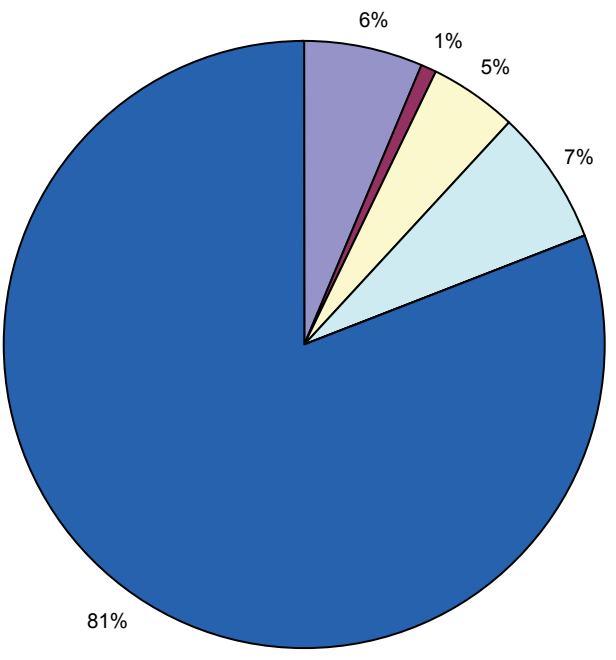

Respecto a los reportajes de efemérides, se han considerado como tal 6 de los 58 reportajes que forman la muestra de estudio. Tres de esos reportajes pertenecen al área de internacional, dos al de nacional y uno al de sociedad. En total, han utilizado un 19\% de imágenes de documentación. De ese porcentaje, un $12 \%$ pertenecen a imágenes recientes frente a un 7\% de imágenes lejanas (sólo se han utilizado imágenes noticia lejanas). 


\section{REPORTAJES LIGADOS A LA ACTUALIDAD INMEDIATA}

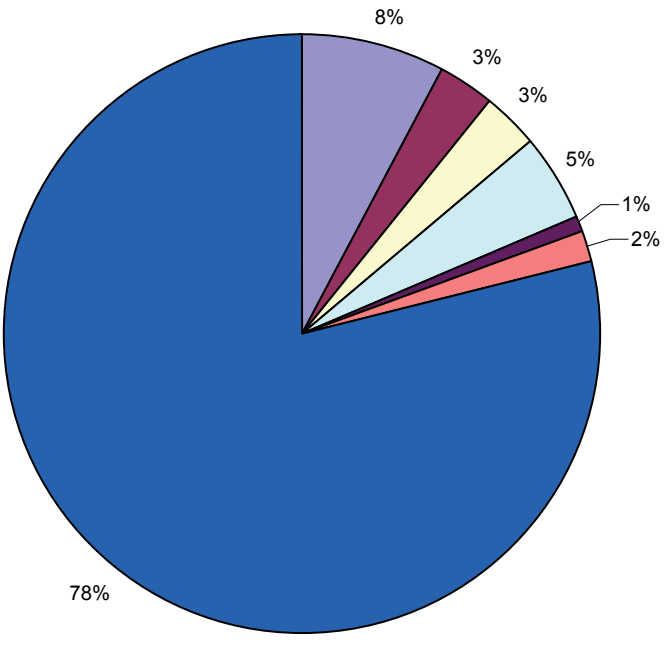

$\square$ Imágenes noticia recientes

口Imágenes metonímicas recientes

$\square$ Imágenes ambientales recientes

$\square$ Imágenes noticia lejanas

- Imágenes metonímicas lejanas

$\square$ Imágenes ambientales lejanas

$\square$ Imágenes producción y grabaciones propias

En lo referente a los reportajes ligados a la actualidad inmediata, 26 de los 58 reportajes han sido incluidos en esta categoría (10 de internacional, 9 de sociedad, 5 de nacional y 2 de cultura), utilizando un $22 \%$ de imágenes de archivo. En este tipo de reportajes predominan las imágenes recientes (14\%) frente a las imágenes lejanas $(8 \%)$. Además, las imágenes noticias (casi un 13\%) predominan sobre las ambientales $(5 \%$ ) y metonímicas $(4 \%)$. 


\section{REPORTAJES LIGADOS A LA ACTUALIDAD PRÓXIMA}

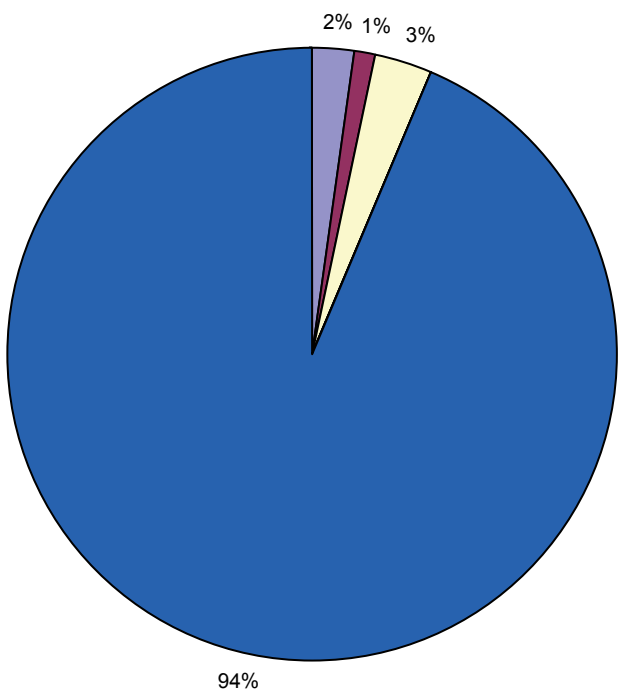

$\square$ Imágenes noticia recientes

$\square$ Imágenes metonímicas recientes

$\square$ Imágenes ambientales recientes

$\square$ Imágenes noticia lejanas

$\square$ Imágenes metonímicas lejanas

$\square$ Imágenes ambientales lejanas

$\square$ Imágenes producción y grabaciones propias

De los 58 reportajes, 13 han sido incluidos en la categoría de reportajes ligados a la actualidad próxima: 5 del área de economía, 4 de sociedad, 3 de internacional y 1 de cultura. En ellos se han utilizado alrededor de un 6\% de imágenes de archivo siendo todas ellas imágenes recientes ya que sólo en el reportaje "Entre la miseria y la guerra", emitido el 4 de abril de 2009, nos encontramos con imágenes noticia lejanas de un campo de desplazados en Gaza tras la guerra de 1948. Se incluyen para mostrar la semejanza con los campos de desplazados actuales. Estas imágenes apenas representan un $0,1 \%$ en este tipo de reportajes. 


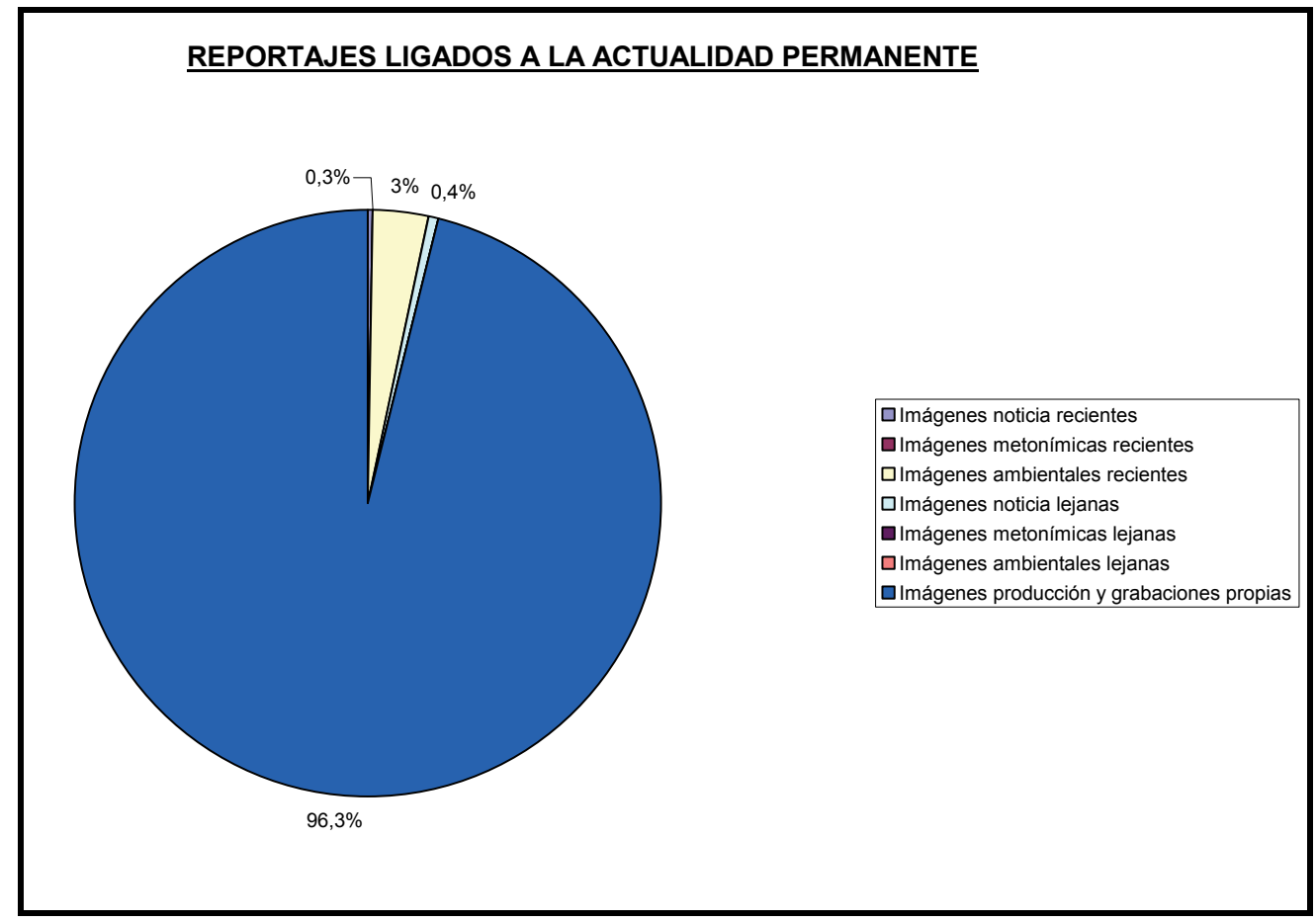

Respecto a los reportajes ligados a la actualidad permanente, 6 de los reportajes han sido considerados como tal (4 de sociedad, 1 de cultura y otro de internacional) y en ellos el uso de imágenes ha sido de casi un $4 \%$, predominando las imágenes recientes (poco más de un 3\%) frente a las imágenes históricas. Sólo en el reportaje "Dioses, tumbas y sabios" se han incluido imágenes lejanas, concretamente, imágenes noticia lejanas de la expedición a Egipto del profesor Martín Almagro Basch. Con respecto a las imágenes recientes, predominan las imágenes ambientales (3\%) frente a las imágenes noticia $(0,3 \%)$. No se han utilizado imágenes metonímicas. 


\section{REPORTAJES DE CULTURA}

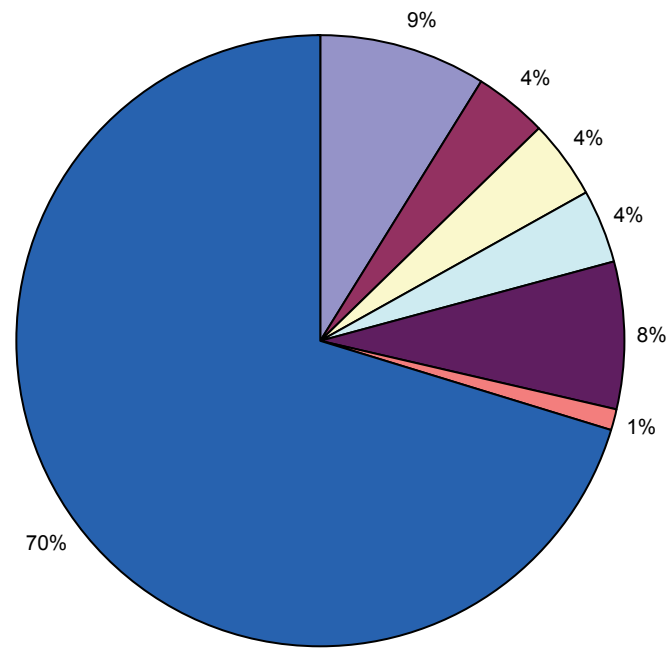

$\square$ Imágenes noticia recientes

$\square$ Imágenes metonímicas recientes

$\square$ Imágenes ambientales recientes

$\square$ Imágens noticia lejanas

$\square$ Imágens metonímicas lejanas

$\square$ Imágenes ambientales lejanas

$\square$ Imágenes producción y grabaciones propias

En el estudio se han clasificado nueve reportajes como pertenecientes al área de cultura. Éstos han utilizado un 30\% de imágenes de documentación, predominando las imágenes recientes (17\%) frente a las imágenes lejanas (un 13\%). En este tipo de reportajes destaca el uso de imágenes noticia (13\%) y de imágenes metonímicas $(12 \%)$ frente a las ambientales $(5 \%)$. 


\section{REPORTAJES DE ECONOMÍA}

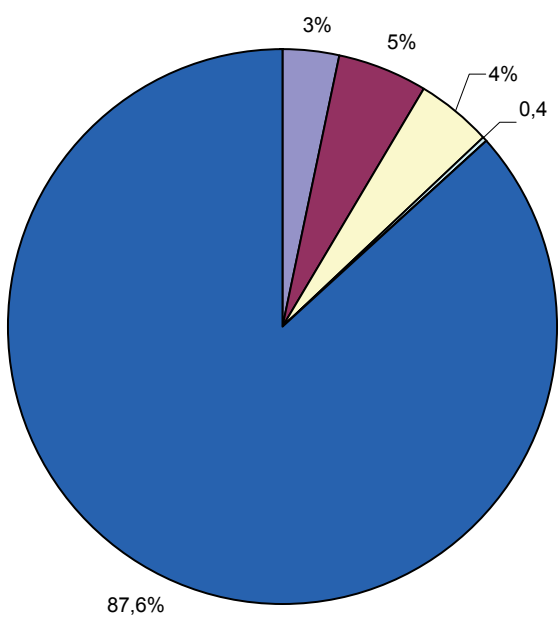

$\square$ Imágenes noticia recientes

$\square$ Imágenes metonímicas recientes

$\square$ Imágenes ambientales recientes

$\square$ Imágenes noticia lejanas

口 Imágenes metonímicas lejanas

$\square$ Imágenes ambientales lejanas

$\square$ Imágenes producción y grabaciones propias

Siete reportajes han sido incluidos en el área de economía, utilizando alrededor de un $12 \%$ de imágenes de documentación. Sólo en el reportaje biográfico "Elena Salgado, la cartera de la crisis", emitido el 18 de abril de 2009, se han incluido imágenes lejanas $(0,2 \%$ de imágenes noticia lejanas). En este tipo de reportajes se han utilizado mayoritariamente imágenes metonímicas $(5 \%)$ seguidas de ambiéntales $(4 \%)$ y de imágenes noticia (alrededor del 3\%). 


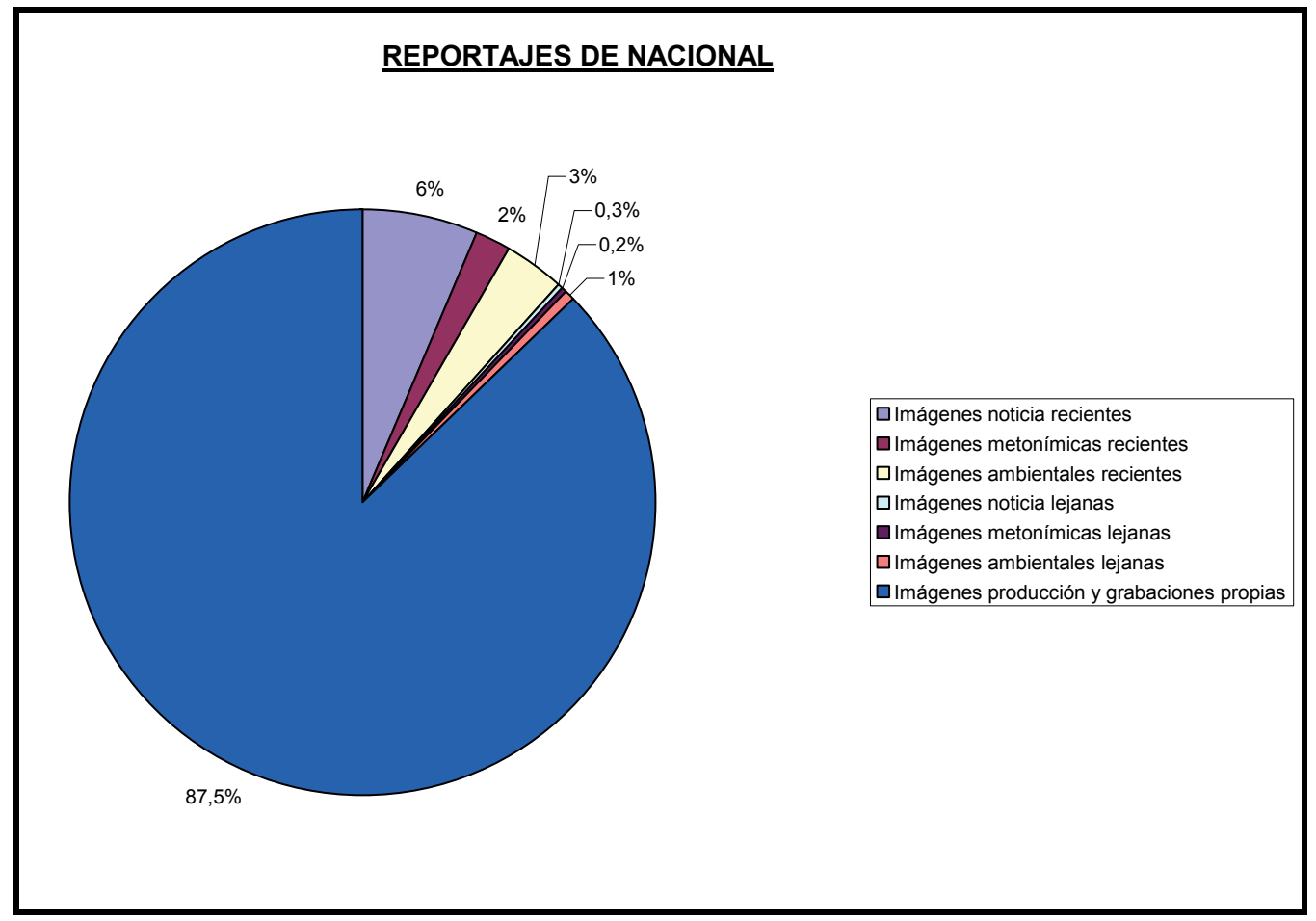

Seis reportajes se han incluido en el área de nacional. En ellos se han utilizado más de un $12 \%$ de imágenes de documentación, predominando las imágenes recientes $(11 \%)$ frente a las imágenes lejanas (poco más de 1\%) ya que sólo en el reportaje "El dinero rojo" se ha utilizado imágenes lejanas. Del total de imágenes de documentación utilizadas, la mitad son imágenes noticia $(6 \%)$, frente a las imágenes ambientales $(4 \%)$ y metonímicas (algo más de un $2 \%$ ). 


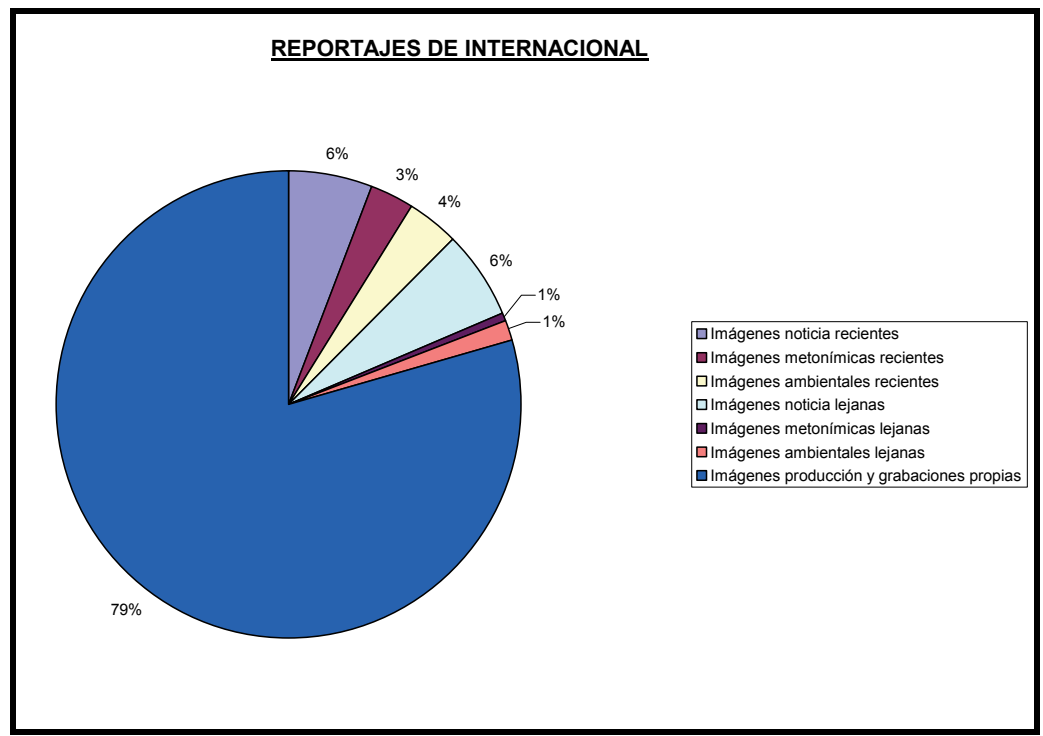

Respecto al área de internacional, 18 de los reportajes se han incluido en esta categoría. En total, han utilizado un $21 \%$ de imágenes de archivo, de las cuales más de un $13 \%$ pertenecen a imágenes recientes y un $8 \%$ a imágenes lejanas. Predominan claramente las imágenes noticia (12\%) frente a las ambientales (5\%) y las metonímicas $(4 \%)$.

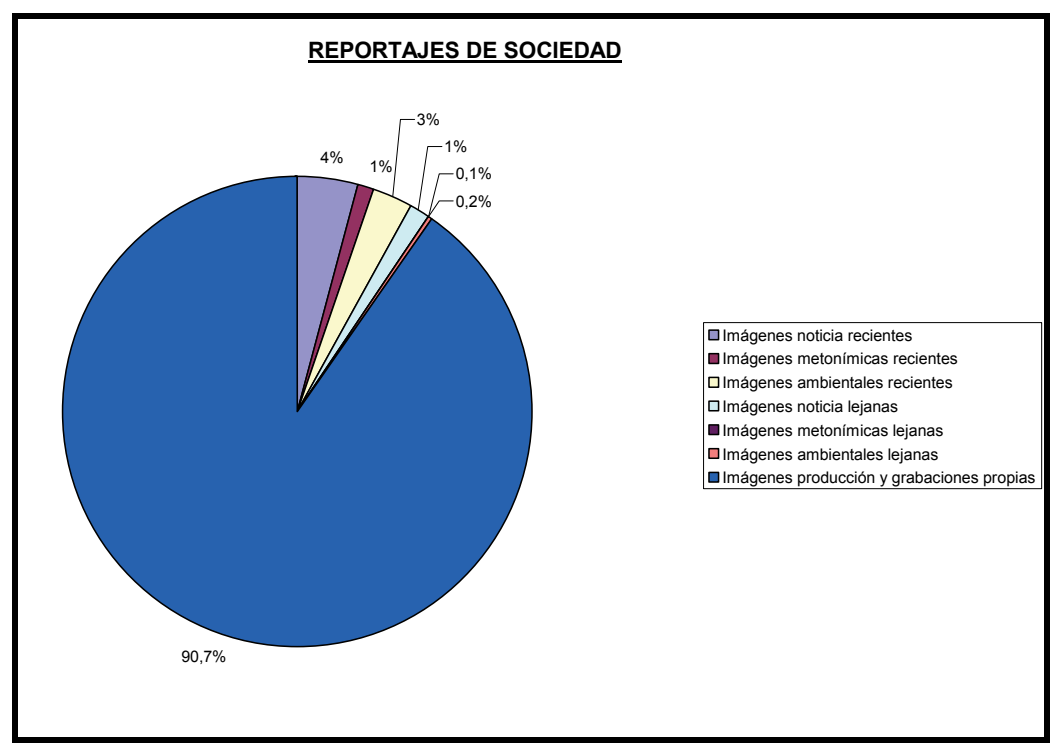


En lo referente al área de sociedad, se han incluido 18 reportajes que han utilizado poco más de un $9 \%$ de imágenes de archivo. De ellas, apenas un $1 \%$ son imágenes lejanas ya que sólo en el reportaje "La vuelta de Pepe El Popular", emitido el 18 de abril de 2009, se han utilizado este tipo de imágenes. Son mayoritarias las imágenes noticia (casi un 5\%) seguidas por las imágenes ambientales (3\%) y las metonímicas (poco más de un $1 \%$ )

\section{Imágenes de archivo utilizadas al inicio o al final de los reportajes}

Autores como Elena Bandrés, José A. García Avilés, Gabriel Pérez y Javier Pérez ${ }^{11}$ o Manuel Artero ${ }^{12}$ insisten en la importancia de captar la atención del espectador desde el inicio del reportaje, por lo que es necesario utilizar un "gancho" o percha". De igual forma, el final del reportaje o la última frase no pueden ser casuales. En la muestra estudiada, 6 reportajes comienzan con imágenes de archivo (algo más de un 10\%), 11 finalizan con ellas (más de un 19\%) y en 3 de ellos se ha optado por iniciar y finalizar el reportaje con imágenes de documentación $(5 \%)$.

\begin{tabular}{|c|c|c|c|c|}
\hline Reportaje & Área & Clasificación & $\frac{\text { Inicio del }}{\text { reportaje }}$ & Final del reportaje \\
\hline $\begin{array}{l}\text { Una isla en la } \\
\text { corriente } \\
(03 / 01 / 2009)\end{array}$ & Internacional & $\begin{array}{l}\text { Reportaje de } \\
\text { efemérides }\end{array}$ & $\begin{array}{l}\text { Imágenes noticia } \\
\text { lejanas }\end{array}$ & \\
\hline $\begin{array}{l}\text { Ribadelago, la } \\
\text { memoria oculta } \\
(10 / 01 / 2009)\end{array}$ & Sociedad & Efemérides & & $\begin{array}{l}\text { Imágenes noticia } \\
\text { lejanas (fotografías) }\end{array}$ \\
\hline $\begin{array}{l}\text { Vacuna Made in } \\
\text { Spain }(17 / 01 / 2009)\end{array}$ & Sociedad & $\begin{array}{l}\text { Actualidad } \\
\text { próxima }\end{array}$ & & $\begin{array}{l}\text { imágenes } \\
\text { ambientales } \\
\text { recientes }\end{array}$ \\
\hline $\begin{array}{l}\text { Esperando a Obama } \\
(17 / 01 / 2009)\end{array}$ & Internacional & $\begin{array}{l}\text { Actualidad } \\
\text { inmediata }\end{array}$ & & $\begin{array}{l}\text { imágenes } \\
\text { metonímicas } \\
\text { recientes }\end{array}$ \\
\hline $\begin{array}{l}\text { El banquero de los } \\
\text { pobres }(24 / 01 / 2009)\end{array}$ & Economía & Biográfico & $\begin{array}{l}\text { Imágenes } \\
\text { metonímicas } \\
\text { recientes }\end{array}$ & $\begin{array}{l}\text { imágenes } \\
\text { metonímicas } \\
\text { recientes }\end{array}$ \\
\hline $\begin{array}{l}\text { La crisis de los } \\
\text { pequeños } \\
(31 / 01 / 2009))\end{array}$ & Economía & $\begin{array}{l}\text { Actualidad } \\
\text { próxima }\end{array}$ & & $\begin{array}{l}\text { imágenes } \\
\text { ambientales } \\
\text { recientes }\end{array}$ \\
\hline $\begin{array}{l}\text { Las favoritas de los } \\
\text { Goya }(31 / 01 / 2009)\end{array}$ & Cultura & $\begin{array}{l}\text { Actualidad } \\
\text { inmediata }\end{array}$ & $\begin{array}{l}\text { Imágenes noticia } \\
\text { recientes }\end{array}$ & \\
\hline
\end{tabular}

${ }^{11}$ BANDRÉS, Elena et al. El periodismo en la televisión digital. Barcelona, Paidós, 2000. pp.164.

${ }^{12}$ ARTERO, Manuel. El guión en el reportaje informativo. Un guiño a la noticia. Madrid, IORTV, 2004, pp.124. 


\begin{tabular}{|c|c|c|c|c|}
\hline $\begin{array}{l}\text { Politkovskaya, la } \\
\text { sombra de un juicio } \\
(07 / 02 / 2009)\end{array}$ & Internacional & $\begin{array}{l}\text { Actualidad } \\
\text { inmediata }\end{array}$ & $\begin{array}{l}\text { Imágenes noticia } \\
\text { recientes }\end{array}$ & \\
\hline $\begin{array}{l}\text { El nuremberg } \\
\text { asiático (21-02- } \\
\text { 2009) }\end{array}$ & Internacional & Efemérides & & $\begin{array}{l}\text { imágenes } \\
\text { ambientales } \\
\text { recientes }\end{array}$ \\
\hline $\begin{array}{l}\text { Darwin ¿De dónde } \\
\text { venimos? } \\
(21 / 02 / 2009)\end{array}$ & Cultura & Biográfico & & $\begin{array}{l}\text { imágenes } \\
\text { ambientales } \\
\text { recientes }\end{array}$ \\
\hline $\begin{array}{l}\text { El Oscar de Pe } \\
(28 / 02 / 2009)\end{array}$ & Cultura & Biográfico & & $\begin{array}{l}\text { imágenes } \\
\text { metonímicas } \\
\text { recientes }\end{array}$ \\
\hline $\begin{array}{l}\text { Yihad.es } \\
(07 / 03 / 2009)\end{array}$ & Nacional & Efemérides & $\begin{array}{l}\text { Imágenes noticia } \\
\text { recientes }\end{array}$ & \\
\hline $\begin{array}{l}\text { La segunda vida de } \\
\text { Andrés (14/03/2009) }\end{array}$ & Sociedad & $\begin{array}{l}\text { Actualidad } \\
\text { inmediata }\end{array}$ & $\begin{array}{l}\text { Imágenes noticia } \\
\text { recientes }\end{array}$ & \\
\hline $\begin{array}{l}\text { Ulster, la paz } \\
\text { amenazada } \\
(14 / 03 / 2009) \\
\end{array}$ & Internacional & $\begin{array}{l}\text { Actualidad } \\
\text { inmediata }\end{array}$ & $\begin{array}{l}\text { Imágenes noticia } \\
\text { recientes }\end{array}$ & \\
\hline $\begin{array}{l}20 \text { años de } \\
\text { impunidad } \\
(21 / 03 / 2009) \\
\end{array}$ & Internacional & $\begin{array}{l}\text { Actualidad } \\
\text { inmediata }\end{array}$ & $\begin{array}{l}\text { Imágenes noticia } \\
\text { lejanas }\end{array}$ & $\begin{array}{l}\text { Imágenes noticias } \\
\text { lejanas }\end{array}$ \\
\hline $\begin{array}{l}\text { Ciudades con } \\
\text { conciencia verde } \\
(04 / 04 / 2009)\end{array}$ & Economía & $\begin{array}{l}\text { Actualidad } \\
\text { próxima }\end{array}$ & & $\begin{array}{l}\text { imágenes } \\
\text { ambientales } \\
\text { recientes }\end{array}$ \\
\hline $\begin{array}{l}\text { El regreso de un } \\
\text { mito: Miguel de } \\
\text { Molina }(4 / 04 / 2009)\end{array}$ & Cultura & Biográfico & & $\begin{array}{l}\text { Imágenes } \\
\text { metonímicas lejanas } \\
\text { (fotografías) }\end{array}$ \\
\hline $\begin{array}{l}\text { Los últimos de } \\
\text { Guantánamo } \\
(18 / 04 / 2009)\end{array}$ & Internacional & $\begin{array}{l}\text { Actualidad } \\
\text { próxima }\end{array}$ & $\begin{array}{l}\text { Imágenes noticia } \\
\text { recientes }\end{array}$ & $\begin{array}{l}\text { imágenes } \\
\text { metonímicas } \\
\text { recientes }\end{array}$ \\
\hline $\begin{array}{l}\text { Sobre Dioses } \\
\text { tumbas y sabios } \\
(18 / 04 / 2009)\end{array}$ & Cultura & $\begin{array}{l}\text { Actualidad } \\
\text { permanente }\end{array}$ & & $\begin{array}{l}\text { imágenes } \\
\text { ambientales } \\
\text { recientes }\end{array}$ \\
\hline $\begin{array}{l}\text { Yak } 42,6 \text { años en la } \\
\text { tiniebla } \\
(25 / 04 / 2009)\end{array}$ & Nacional & $\begin{array}{l}\text { Actualidad } \\
\text { inmediata }\end{array}$ & & $\begin{array}{l}\text { imágenes } \\
\text { metonímicas } \\
\text { recientes } \\
\text { (fotografías) }\end{array}$ \\
\hline
\end{tabular}

\section{Relación de reportajes que comienzan o finalizan con imágenes de archivo}

A partir de los datos obtenidos podemos señalar:

1. Hay un predominio de los reportajes de internacional, así como los de actualidad inmediata que comienzan con imágenes de archivo, siendo la mayoría imágenes noticia recientes.

2. Con respecto al final del reportaje, son también mayoría los reportajes de internacional, junto con los de cultura. Predominan además los reportajes de actualidad 
inmediata y los biográficos. La mayoría de las imágenes de archivo utilizadas son imágenes ambientales recientes y metonímicas recientes.

\section{$\underline{\text { Reutilización por parte de Informe Semanal de sus propias imágenes }}$}

Se ha podido comprobar en el visionado de seis reportajes cómo el programa reutiliza sus propias imágenes. Concretamente, en los siguientes reportajes:

- "Sin noticias de Marta" (emitido el 7 de febrero de 2009)

- "Yak 42, 6 años en la tiniebla" (emitido 25 de abril de 2009)

- "La segunda vida de Andrés" (emitido el 14 de febrero de 2009)

- En los reportajes "Esperando a Obama" (17/01/2009), "Presidente Obama" (24/01/2009) y "Los últimos de Guantánamo" (18/04/200) donde se ha utilizado imágenes de la cárcel de Guantánamo procedentes del reportaje Informe Semanal "Guantánamo, la cárcel de la vergüenza"13, emitido el 12 de enero de 2008.

En los tres primeros casos, esas imágenes se han reutilizado en reportajes que volvían a tratar el tema en el que se centraba el primer reportaje para el que se grabaron esos brutos y que de nuevo volvía a saltar a la actualidad. De esta forma, las imágenes rodadas para anteriores reportajes se reutilizan como imágenes recientes para recordar al telespectador el anterior reportaje y los datos que se proporcionaron en él.

En el caso de las imágenes de la cárcel de Guantánamo, se incluyeron en un reportaje sobre el cierre de Guantánamo ("Los últimos de Guantánamo" emitido el 18 de abril de 2009) y en otros dos reportajes donde el tema de Guantánamo ocupaba parte del reportaje, pero no era el tema principal: "Esperando a Obama" (17/01/2009) y "Presidente Obama" (24/01/2009).

El caso más llamativo es el del reportaje "La segunda vida de Andrés", emitido el 14 de marzo de 2009. En él se cuenta el éxito del transplante realizado a Andrés Mariscal a partir de la sangre del cordón umbilical de su hermano Javier, el primer "bebe medicamento" de España. Unos meses antes, el 29 de noviembre de 2008, Informe Semanal había ya emitido un reportaje sobre los "niños medicamentos" con motivo del nacimiento en el mes de octubre de Javier, titulado "Más que hermanos ${ }^{14 ، .}$.

En "La segunda vida de Andrés" más del $58 \%$ de las imágenes del reportaje pertenecen a las imágenes emitidas en "Más que hermanos". Incluso reutiliza una parte del audio del primer reportaje:

"Si esa célula no tiene la enfermedad querrá decir que el embrión es sano y se podrá transferir al útero de la madre. Una técnica compleja pensada para parejas con alto riesgo de transmitir enfermedades genéticas a sus hijo"

\footnotetext{
${ }^{13}$ Informe Semanal, no 1067. "Guantánamo, la cárcel de la vergüenza”. Emitido el 12 de enero de 2008.

${ }^{14}$ Informe Semanal. no 1108. "Más que hermanos” Emitido el 29 de noviembre de 2008.
} 
Al incluirse las imágenes del primer reportaje nos encontramos con que las imágenes emitidas en "Más que hermanos" se reutilizan como imágenes metonímicas, ambientales y noticia recientes. En esta última categoría se han incluido las entrevistas grabadas para el primer reportaje que aparecieron en la emisión y que de nuevo se usan en el segundo. Como vemos, no sólo se reutilizan las imágenes, sino también las entrevistas e incluso parte del off del primer reportaje.

El hecho de que en "La segunda vida de Andrés" se haya reutilizado una cantidad importante de material del primer reportaje puede deberse a que la noticia del éxito del transplante y la rueda de prensa dada por el hospital se produjo el viernes 13 de marzo, por lo que el programa tuvo que preparar rápidamente otro reportaje para incluirlo en el programa del día siguiente.

Es interesante señalar que el primer reportaje finalizaba con las imágenes de la familia de Andrés viajando hacia Sevilla para el niño se sometiera al tratamiento previo al transplante. El segundo reportaje comenzaba precisamente con esas imágenes y un audio también similar:

\section{OFF “ALGO MÁS QUE HERMANOS” (29/11/2009):}

"Algeciras, cinco y media de la mañana. Todavía no ha amanecido, pero la familia de Javier y Andrés está impaciente. Hoy les recibe el hematólogo en Sevilla. Son las últimas pruebas antes del transplante. Kilómetros de carretera que acercan a Andrés a la vida y convierten a Javier en algo mas que un hermano"

\section{OFF “LA SEGUNDA VIDA DE ANDRÉS” (14/03/2009):}

"Son las cinco y media de la mañana y todavía no ha amanecido en Algeciras pero los padres de Andrés y Javier ya están en pie. Hoy le recibe el hematólogo en Sevilla. Serán las últimas pruebas antes del transplante"

Tras estas imágenes, en "La Segunda vida de Andrés" se incluyen imágenes de la llegada ese día de la familia del niño al hospital de Sevilla para dar luego paso a imágenes de la rueda de prensa en el hospital el 13 de marzo de 2009 con el siguiente off:

"Hoy, casi cuatro meses después sabemos que el transplante ha sido un éxito. Andrés cumplió el jueves siete años. Todavía no ha podido celebrarlo. Ha estado cinco semanas en una sala estéril pero ha recibido ya su mejor regalo. Ha recuperado su infancia. Es un niño sano, ha salvado su vida gracias a su hermano"

En este caso, las imágenes de archivo que aparecen al inicio del segundo reportaje sirven para enlazar con el final del primer reportaje y para recordar la historia que el 
programa ya había tratado hacía ya varios meses. Pero también se grabaron para el especial informativo El alma de los verdugos II. El poder de las tinieblas ${ }^{15}$, emitido el 13 de marzo de 2008, por lo que se volverá a mencionar más adelante cuando hablemos de cómo se reutilizan imágenes de otros programas informativos no diarios.

\section{Utilización de documentos especiales}

Como se indicó anteriormente, se ha incluido en los documentos especiales:

- Imágenes de películas y documentales.

- Imágenes de videoaficionado.

- Fotografías.

\section{Secuencias de películas y documentales. Las imágenes ficticias.}

En programas informativos diarios ${ }^{16}$ a menudo se recurre a la utilización de secuencias de películas con distintos usos:

- Cuando la película es, de alguna manera, "noticia".

- Cuando la noticia trata de sus protagonistas, es decir, las secuencias cumplen una función metonímica.

- Cuando cumplen una función ambiental o ilustrativa. Este uso es menor.

De los 58 reportajes estudiados, 8 de ellos han incluido imágenes de películas o documentales (un 14\% de los reportajes estudiados) ${ }^{17}$.

Así en "Una isla en la corriente", emitido el 1 de enero de 2009, se incluye una secuencia de "Fresa y chocolate" (Tomás Gutiérrez Alea, 1993) para hablar del estreno de la película en Cuba y que sirve también como pretexto para dar paso a una entrevista con su protagonista, Jorge Perugorría. En este caso se trata de una secuencia utilizada como imagen noticia lejana.

En el reportaje "Las favoritas de los Goya", emitido el 31 de enero de 2009, se utiliza constantemente imágenes de las cuatro películas nominadas al Goya a la mejor película; Camino (Javier Fesser), Los crímenes de Óxford (Alex de la Iglesia), Sólo quiero caminar (Agustín Díaz Yanes) y Los girasoles ciegos (José Luis Cuerda) Se usan por tanto como imágenes noticia recientes. También en este reportaje se incluyen imágenes de la película Nadie hablará de nosotras cuando hayamos muerto (Agustín Díaz Yanes, 1995) para recordar que su director ganó el Goya al mejor director en 1995 por esa película. Se usan por tanto como imágenes noticia lejanas. Un uso similar es el

\footnotetext{
${ }^{15}$ El alma de los verdugos II. El poder de las tinieblas. Especial informativo emitido el 13 de marzo de 2008.

${ }^{16}$ Opus. Cit. pp. 291-92, 373-74 y 437-38.

${ }^{17}$ Se trata de los reportajes "Una isla en cola corriente", "Las favoritas de los Goya", "El oscar de Pe", "Bacon, la mirada oblicua" "Dioses, tumbas y sabios", "El banquero de los pobres", "Valkiria, objetivo matar a Hitler" y "Miguel de Molina: el regreso de un mito".
} 
de las imágenes de varias secuencias de películas de Jesús Franco, premiado con el Goya de honor.

En el reportaje "El oscar de Pe", emitido el 28 de febrero de 2009, se han utilizado varias secuencias de películas. Por un lado, nos encontramos con imágenes noticia recientes e imágenes noticia lejanas de las películas Vicky, Cristina Barcelona (Woody Allen, 2008), Jamón, Jamón (Bigas Luna, 1992), Volaverunt (Bigas Luna, 1999), El amor perjudica seriamente la salud (Manuel Gómez Pereira, 1996), La niña de tus ojos (Fernando Trueba, 1998), Carne Trémula (Pedro Almodóvar, 1997) No te muevas (Sergio Castellitto, 2004) o Elegy (Isabel Coixet, 2008). Todas ellas se utilizan para recordar la carrera cinematográfica de Penélope Cruz.

Por otro lado, hay tres secuencias de películas utilizadas como imágenes metonímicas recientes o imágenes metonímicas lejanas. Es el caso de una secuencia de Volaverunt (Bigas Luna, 1999) que ilustra unas palabras de su director sobre la belleza de la mirada de Penélope Cruz. Un caso similar es el de la secuencia de Belle Epoque (Fernando Trueba, 1992) que acompaña la entrevista a Trueba cuando recuerda el casting que realizó a la actriz. Finalmente, nos encontramos con un uso peculiar que roza casi la metáfora; una secuencia de Abre los ojos (Alejandro Amenábar, 1997) da paso a otra secuencia muy similar de la versión americana de la película, Vanilla Sky (Cameron Crowe, 2001) para hablar de la carrera cinematográfica de la actriz en Hollywood.

También en el reportaje "El regreso de un mito: Miguel de Molina", emitido el 4 de abril de 2009, se incluyen secuencias de películas protagonizadas por el artista para hablar de su vida profesional y personal. Todas ellas se utilizan como imágenes metonímicas lejanas.

El reportaje "Bacon, la mirada Oblicua", emitido el 7 de febrero de 2009, comienza con la famosa imagen del corte del ojo del cortometraje El perro Andaluz" (Luis Buñuel, 1929) y posteriormente se da paso a unas de trabajadores empujando unas terneras abiertas en canal, otras de Pablo Picasso dibujando la silueta de un toro en un cristal y otras de unos ciudadanos desfilando con uso fusiles al hombro. Todas estas imágenes en blanco y negro intentan reflejar el universo del pintor Francis Bacon. Por ello, se ha considerado que en este caso la secuencia de la película de Luis Buñuel es utilizada como imagen ambiental lejana.

En el reportaje "Dioses, tumbas y sabios", emitido el 25 de abril de 2009, se utilizan como imágenes noticia lejanas unas imágenes del documental Cuarenta siglos os contemplan (José María Alonso Pesquera, 1968) para hablar de la expedición que realizó Martín Almagro a Egipto en los años sesenta. En el reportaje "El banquero de los pobres" se utiliza más de un $40 \%$ de imágenes del documental El ejército de los pobres $^{18}$ que se emitió en el espacio de TVE "La noche temática". En ningún momento se rotulan o se menciona que dichas imágenes no han sido grabadas por el programa y que pertenecen a ese documental.

\footnotetext{
${ }^{18}$ Documental dirigido por Jorge Iglesias en 2002 y producido por New Atlantis.
} 
En el reportaje "Valkiria, objetivo matar a Hitler", emitido el 31 de enero de 2009, se han incluido numerosas imágenes del documental Sólo contra Hitler ${ }^{19}$ y tampoco se indica la procedencia de dichas imágenes.

Otro documental utilizado es el fragmento de la entrevista de David Sylvester a Francis Bacon en Francis Bacon, fragments of a portrait (1966) de la BBC, utilizada como imágenes noticia lejanas. Las imágenes están rotuladas indicando su procedencia.

Finalmente, se han utilizado imágenes procedentes de noticiarios cinematográficos. Ese es el caso del reportaje "Ribadelago, la memoria sumergida", emitido el 10 de enero de 2009 donde se ha utilizado el NO-DO que narraba la tragedia como imágenes noticias lejanas. En "El dinero rojo", emitido el 14 de marzo de 2009, se utilizan imágenes de noticiarios como imágenes noticia lejanas (las imágenes de enfrentamientos durante la Guerra Civil), imágenes metonímicas lejanas (se incluyen unas imágenes de Franco) y ambientales lejanas (imágenes de dinero republicano).

Durante el estudio hemos detectado la utilización de secuencias de películas con un uso novedoso al que hemos prestado especial atención: la utilización de films para ilustrar determinados acontecimientos históricos o reflejar la vida de un personaje. A este nuevo uso le hemos denominado "imágenes ficticias"

En el reportaje "Valkiria, objetivo matar a Hitler", emitido el 31 de enero de 2009, con motivo del inminente estreno de la película protagonizada por Tom Cruise y basada en el intento de asesinato de Hitler por parte del coronel alemán Claus von Stauffenberg, se incluyen numerosas secuencias de la película utilizadas como imágenes noticia. Sin embargo, en un momento determinado se incluyen varias secuencias en las que aparece el protagonista en distintos momento del film. El off dice:

“Tercer hijo de una familia profundamente política, Stauffenberg había optado por la carrera militar. Se aleja pronto de Hitler y de las ideas del Nacional-Socialismo. Destinado en África, pierde un ojo, una mano, y varios dedos de la otra. De vuelta en Berlín es nombrado responsable del ejército de reserva, lo que le permitirá estar muy cerca del Fuhrer. Ha madurado la posibilidad de asesinarle y hacer caer al régimen poniendo en marcha la operación Valkiria. Movilizará a los reservistas haciéndoles creer que están protegiendo al gobierno"

Un caso similar lo encontramos en el reportaje biográfico "El regreso de un mito: Miguel de Molina", emitido el 4 de abril de 2009. En él se incluye una secuencia de la película Las cosas del querer (Jaime Chávarri, 1989), en la que a Manuel Bandera, que interpreta a Miguel de Molina, le dan una paliza. A la secuencia le acompañan unas imágenes y el audio de una entrevista en un programa de Canal Sur a Miguel de Molina en la que recordaba aquella paliza que le obligó a marcharse de España.

Tanto en el caso del reportaje referente al estreno de Valkiria, como en el reportaje sobre Miguel de Molina, nos encontramos con que se utilizan imágenes de las películas

\footnotetext{
${ }^{19}$ Sólo contra Hitler (Allein gegen den Fuhrer). Dirigido por Rudiger Liedtke. Alemania, WDR, 1989.
} 
en las que aparecen los actores Tom Cruise y Manuel Bandera para ilustrar distintos momentos de la vida de Claus von Stauffberg y Miguel de Molina, respectivamente.

\section{Utilización de fotografías}

En la muestra de reportajes estudiada se incluyen fotografias utilizadas tanto como imágenes noticia (lejanas y recientes) como metonímicas (también lejanas y recientes)

Respecto a las fotografías imágenes noticia (lejanas y recientes), se utilizan fundamentalmente en tres circunstancias:

- $\quad$ Para probar que algo ocurrió o existió: como la fotografía aérea de las instalaciones de los misiles en los años sesenta en "Una isla en la corriente", la fotografía de la cacería a la que asistieron el ex ministro de Justicia Mariano Fernández Bermejo y el juez Baltasar Garzón en "Tormenta política sobre Madrid" o la fotografía de una playa de Lanzarote que inspiró a Pedro Almodóvar para rodar la película Los abrazos rotos en "La pasión según Almodóvar"

- $\quad$ En el caso de los reportajes biográficos, se utilizan para ilustrar un momento de la vida del personaje del que sólo se tienen esas imágenes (como las fotografías de José Antonio Labordeta en el Colegio Alemán en "Labordeta, de frente" o la del encuentro entre Francis Bacon y Juan Cruz en "Bacon, la mirada oblicua").

- $\quad$ Para ilustrar un acontecimiento del que no se tienen imágenes en movimiento (como la fotografía del Dalai Lama camino del exilio en el reportaje "Tibet, medio siglo ocupado" o imágenes de las labores de los forenses tras el accidente en "Yak-42, 6 años en la tiniebla)

Por otro lado, se han utilizado fotografías como imágenes metonímicas en los reportajes biográficos para ilustrar algunos momentos de la vida del personaje del que no se tienen documentos audiovisuales (como en "La evolución de Darwin") o, en el caso de los reportajes relacionados con la desaparición y muerte de Marta del Castillo, para mostrar imágenes de la desaparecida de la que sólo se tiene imágenes de un video doméstico y de los detenidos, a la espera de las primeras imágenes tras su arresto.

\section{Videos domésticos}

Este tipo de documentos especiales se caracterizan por tener peor calidad que las imágenes grabadas en formato profesional, por lo que su uso en un programa informativo no diario, donde se cuida con especial esmero la calidad y la estética de las imágenes, debe estar plenamente justificado, como ocurre en los siguientes casos.

El primer video aparece en el reportaje "Sin noticias de Marta", emitido el 7 de febrero de 2009, en él aparecen distintas imágenes de Marta del Castillo antes de su desaparición como imágenes metonímicas recientes. 
El segundo video se incluye en el reportaje "Ulster, la paz amenazada" y se reutiliza como imágenes noticia lejana de gente buscando entre los escombros tras el atentado de Omagh del 15 de agosto de 1998.

\section{Utilización de otros tipos de imágenes}

Como señalamos anteriormente, las imágenes grabadas por los informativos diarios son una fuente a la que recurre Informe Semanal, especialmente cuando esas imágenes son únicas o no hay tiempo para grabar otras. También se acude a los envíos de agencias nacionales e internacionales y a los de Eurovisión, a las señales institucionales $y$ pools. Pero en los reportajes estudiados se han incluido material de otras procedencias, como:

- Imágenes de otros programas informativos no diarios: En el reportaje "El Nuremberg asiático", emitido el 21 de febrero de 2009 , más de un $36 \%$ de las imágenes pertenecen al reportaje del programa En Portada "Utopía y terror: Los jemeres rojos" 20 , emitido el 7 de marzo de 2005. Por otro lado, varias de las imágenes de la cárcel de Guantánamo que se incluyen en los reportajes "Esperando a Obama" (17/01/2009), "Presidente Obama" (24/01/2009) y "Los últimos de Guantánamo" (18/04/2009) pertenecen al reportaje de Informe Semanal "Guantánamo, la cárcel de la vergüenza" 21 , emitido el 12 de enero de 2008, y al especial informativo El alma de los verdugos II. El poder de las tinieblas ${ }^{22}$, emitido el 13 de marzo de 2008.

- Imágenes de programas no informativos: Es el caso de las imágenes del programa Un país en la mochila que se incluyen en el reportaje "Labordeta, de frente" como imágenes noticia para hablar del programa que presentó José Antonio Labordeta

- Emisiones de programas informativos diarios: En el reportaje "La vuelta de Pepe el del Popular", emitido el 18 de abril de 2009, se reutiliza la emisión de un telediario de 1991 en el que la presentadora Elena Sánchez da paso a una pieza sobre dos mujeres que contaban la estafa que habían sufrido.

- Imágenes procedentes de otras cadenas de televisión: Es el caso de la entrevista en Canal Sur a Miguel de Molina que aparece en "El regreso de un mito: Miguel de Molina" (4/04/2009) y la entrevista a Francis Bacon de la BBC.

\footnotetext{
${ }^{20}$ En Portada. "Utopía y terror: Los jemeres rojos". Reportaje elaborado por Vicente Romero y realizado por J. Carlos Ribas. Emitido el 7 de marzo de 2005.

${ }^{21}$ Informe Semanal, $\mathrm{n}^{\circ}$ 1067. "Guantánamo, la cárcel de la vergüenza". Emitido el 12 de enero de 2008 .

${ }_{22}$ El alma de los verdugos II. El poder de las tinieblas. Especial informativo emitido el 13 de marzo de 2008 .
} 


\section{$\underline{\text { Rotulación de las imágenes }}$}

La rotulación de imágenes de archivo en los programas informativos diarios suele ser poco común y arbitraria. Una mala rotulación o la inexistencia de ella pueden llevar a la confusión al espectador. En el caso de Informe Semanal, se ha constatado que tampoco es habitual rotular las imágenes de archivo y no parece haber unas directrices claras al respecto. Las secuencias de las películas protagonizadas por Penélope Cruz en "El Oscar de Pe" aparecen rotuladas como "Título de la película, director, fecha". Sólo la secuencia de Carne Trémula (Pedro Almodóvar, 1997) aparece sin rotular.

En el reportaje "Una isla en la corriente" la secuencia de Fresa y chocolate (Tomás Gutiérrez Alea, 1994) aparece sin rotular y es el off el que nos da la información sobre la imagen que estamos viendo:

“.. Nos lo confiesa Jorge Perugorría, pintor y elogiado actor por Fresa y chocolate, una película de respeto y tolerancia hacia la diversidad. Se estrenó en los noventa, pero los cubanos no pudieron verla por televisión hasta hace dos años"

En el reportaje "Miguel de Molina; el regreso de un mito", todas las secuencias de las películas protagonizadas por el artista aparecen sin rotular, lo que impide identificarlas ya que tampoco el off proporciona información sobre ellas. Sólo la secuencia ya comentada anteriormente de Las cosas del querer (Jaime Chávarri, 1992) aparece rotulada como "Las cosas del querer, de Jaime Chávarri, 1989". En este caso la rotulación parece más que apropiada ya que la película ilustra un momento concreto de la vida de Miguel de Molina convirtiéndose en "imágenes noticia ficticias". De esta forma, el espectador tiene claro en todo momento que lo que está viendo no es el acontecimiento en sí, si no una película que lo recrea. Sin embargo, las imágenes de Valkiria no aparecen rotuladas, ni siquiera cuando son utilizadas como "imágenes metonímicas ficticias".

En el caso del reportaje "Las favoritas de los Goya", emitido el 31 de enero de 2009, ninguna secuencia de las películas aparecen rotuladas y es el off el que nos proporciona la información necesaria sobre ellas.

En lo referente a los documentales utilizados, sólo aparece rotulada la entrevista a Francis Bacon en la BBC como "Entrevista con David Sylvester (1966). Francis Bacon". En ningún momento se menciona o se rotulan las imágenes procedentes de los documentales Cuarenta siglos os contemplan (José María Alonso Pesquera, 1968), El ejército de los pobres ${ }^{23}$ y Sólo contra Hitler ${ }^{24}$.

En el reportaje "La vuelta de Pepe, el del Popular" aparece, como he mencionado, una pieza del telediario referida al desfalco en 1991. La entradilla de la presentadora aparece sin rotular y es el off el que sirve para situar al espectador en el tiempo: "Así

\footnotetext{
${ }^{23}$ El ejército de los pobres. Dirigido por Jorge Iglesias. España, News Atlantis, 2002.

${ }^{24}$ Sólo contra Hitler (Allein gegen den Fuhrer). Dirigido por Rudiger Liedtke. Alemania, WDR, 1989.
} 
recogía el telediario de hace 18 años como Begoña y Dolores Sáez reclamaban los depósitos de sus libretas a plazo fijo".

Sin embargo, las declaraciones de las dos mujeres en la pieza de aquel informativo sí que aparecen rotuladas como "Afectada, marzo, 1991". También se incluyen unas declaraciones de otro afectado rotuladas como "Vidal Celis, hostelero, "Marzo, 1991". Es decir, se han rotulado aquellas declaraciones que pueden hacer creer al telespectador que está viendo unas declaraciones grabadas ex profeso por el programa para ese reportaje.

En el reportaje "La segunda vida de Andrés" el audio del inicio del reportaje nos indica que estamos viendo imágenes de archivo:

"Son las cinco y media de la mañana y todavía no ha amanecido en Algeciras, pero los padres de Andrés y Javier ya están en pie. Hoy le recibe el hematólogo en Sevilla. Serán las últimas pruebas antes del transplante...."

"Hoy, casi cuatro meses después sabemos que el transplante ha sido un éxito. Andrés cumplió el jueves siete años. Todavía no ha podido celebrarlo. Ha estado cinco semanas en una sala estéril pero ha recibido ya su mejor regalo. Ha recuperado su infancia. Es un niño sano, ha salvado su vida gracias a su hermano.

Posteriormente, el audio proporciona información sobre las imágenes de archivo procedentes del reportaje "Más que hermanos", emitido el 28 de noviembre de 2009:

"Hoy hemos visto a un niño retraído ante las cámaras, pero hace tan solo unas semanas Informe semanal veía su rostro más simpático" (se da paso entonces imágenes de Andrés emitidas en el anterior reportaje).

Sin embargo, ninguna de las imágenes procedentes del anterior reportaje, ni siquiera las declaraciones, son rotuladas.

En el caso del reportaje "Yak 42, seis años en la tiniebla", las declaraciones del general Navarro, asegurando que todos los cadáveres de los soldados iban a identificarse perfectamente, aparecen rotuladas como "General Navarro, (26-05-2003). También se han rotulado las imágenes noticia recientes del funeral de los soldados como "Bases de Torrejón (28-05-2003). Sin embargo, ninguna de las imágenes procedentes del reportaje anterior "La otra historia del Yak-42", emitido el 29 de junio de 2008 están rotuladas y es el audio, como vimos anteriormente, el que proporciona la información.

Se ha dejado para el final el análisis de dos casos de utilización imágenes de archivo sin rotular que hemos considerado incorrectos. En el primer caso, en "El Nuremberg asiático", emitido el 21 de febrero de 2009, se han utilizado más de un $36 \%$ de imágenes de pertenecientes al reportaje, ya mencionado anteriormente, de En Portada "Utopía y terror. Los jemeres rojos". Incluso se reutilizan varios fragmentos de una entrevista. Esto puede llevar a equívocos ya que en ningún momento se menciona la procedencia de dichas imágenes y parece que son imágenes grabadas ex profeso para dicho reportaje, cuando realmente no son imágenes actuales. 
Un caso similar es el del reportaje "El banquero de los pobres", emitido el 24 de enero de 2009, en el que se utilizan numerosas imágenes del documental El ejército de los pobres, incluyendo algunas declaraciones que se alternan con la entrevista realizada por el programa a Muhammad Yunus. En ningún momento se menciona la procedencia de dichas imágenes por lo que parecen tan actuales como la entrevista.

\section{CONCLUSIONES}

Como mencionamos al principio del trabajo, el objetivo de este trabajo es conocer cómo un programa informativo no diario como Informe Semanal utiliza imágenes de archivo en sus reportajes. La división realizada entre imágenes noticia, ambientales y metonímicas nos ha permitido dividir las imágenes según su relación con el sonido que le acompaña y con la noticia y el contexto al que hace referencia. Asimismo, la división entre imágenes recientes y lejanas (grabadas hace diez o más años) nos permite valorar hasta qué punto el programa dirige la mirada al pasado y cómo un programa informativo no diario utiliza imágenes alejadas de la actualidad.

Lamentablemente, en el intervalo de la producción del programa estudiado no se realizó ningún reportaje de deportes, lo que indica el escaso interés del programa por este tipo de reportajes.

Como hemos visto, en todos los programas visionados se han utilizado imágenes de archivo. En 43 reportajes de los 58 estudiados se han utilizado imágenes procedentes de documentación, lo que representa un $74 \%$ de la muestra seleccionada. En total se han utilizado alrededor de un 18\% de imágenes de archivo, de las cuales más de un $13 \%$ son imágenes recientes y alrededor de un $5 \%$ son imágenes lejanas.

A partir del presente trabajo podemos extraer las siguientes conclusiones:

1. En la muestra seleccionada predominan las imágenes noticia $(6 \%$ de imágenes noticia recientes y un $4 \%$ de imágenes noticia lejanas), seguidas de las imágenes metonímicas recientes (4\%) y de las metonímicas lejanas (4\%). El uso de imágenes ambientales recientes y lejanas es escaso (2\%). Esto puede deberse al hecho de que en el programa se presta especial atención a la calidad de las imágenes y no todas las que graba el telediario son aptas para incluirse en Informe Semanal ya que en el programa se necesitan planos más cuidados y largos. Por ello, se prefiere grabar este tipo de imágenes siempre que sea posible.

2. Los reportajes biográficos son los que han utilizado un mayor número de imágenes de archivo (un 32\%). Les siguen los reportajes de actualidad inmediata (22\%) y los de efemérides (19\%). En los reportajes de efemérides predominan claramente las imágenes noticia. En los biográficos predominan las imágenes noticia y metonímicas.

3. Conforme el reportaje se aleja de la actualidad inmediata, también disminuye el uso de imágenes de archivo. En la muestra estudiada, los reportajes ligados a la 
actualidad inmediata han utilizado un $22 \%$ de imágenes de archivo, los ligados a la actualidad próxima un $6 \%$ y los de actualidad permanente casi un $4 \%$.

a. En los reportajes ligados a la actualidad inmediata predominan claramente las imágenes noticia. En los reportajes ligados a la actualidad próxima el uso de imágenes noticia y ambientales es similar. En los reportajes de actualidad permanente se utilizan mayoritariamente las imágenes ambientales.

4. Respecto a la clasificación por áreas, los reportajes de cultura ocupan el primer puesto en la utilización de imágenes de archivo (30\%), seguidos por los de internacional (21\%). Los que menos han utilizado imágenes de archivo son los de economía (12\%), nacional (11\%) y sociedad (9\%)

a. En los reportajes de internacional y nacional se han utilizado mayoritariamente imágenes noticia, seguidas de imágenes ambientales y metonímicas.

b. En los reportajes de cultura el uso de imágenes noticia y metonímicas es bastante similar. Les siguen de lejos las imágenes ambientales.

c. En los reportajes de sociedad ocupan el primer puesto las imágenes noticia, seguidas por las ambientales y las metonímicas.

d. En los reportajes de economía predominan las imágenes metonímicas y ambientales, seguidas por las imágenes noticia.

5. En 20 de los 58 reportajes se ha considerado que las imágenes de archivo tenían suficiente valor e interés como para iniciar o finalizar el reportaje.

6. El programa reutiliza sus propias imágenes principalmente cuando el tema, acontecimiento o personaje que fue actualidad vuelve de nuevo a serlo. Esa reutilización incluye imágenes, declaraciones, entrevistas e incluso el propio off del reportaje origen.

7. Las secuencias de películas pueden servir para recrear un suceso o la vida de una personalidad. En este caso nos encontramos ante un nuevo uso al que hemos denominado "imágenes ficticias". Se propone por tanto, a partir de este trabajo, continuar investigando sobre esta reutilización tanto en programas informativos diarios como en los no diarios. También se usan las imágenes procedentes de películas principalmente como imágenes noticia o metonímicas (tanto lejanas como recientes) y en menor medida como imágenes ambientales (lejanas o recientes).

8. El programa también utiliza fotografías como imágenes noticia (lejanas y recientes) con diferentes fines:

a. Probar que algo ocurrió o existió.

b. En los reportajes biográficos, para ilustrar un momento de la vida del personaje del que sólo se tienen esas imágenes.

c. Para ilustrar un acontecimiento del que no se tienen imágenes en movimiento.

Las fotografías se incluyen como imágenes metonímicas (lejanas y recientes) en los reportajes biográficos para ilustrar algún momento de la vida de una persona del 
que no se tienen documentos audiovisuales. También se utilizan para mostrar imágenes de una persona de las que, en principio, no se tienen otras imágenes.

9. El programa, en el que se cuida de forma especial la calidad de las imágenes, incluye videos domésticos cuando está suficientemente justificada su aparición por el propio valor que tienen.

10. La rotulación de las imágenes de archivo es escasa y arbitraria. Consideramos, sin embargo, que se deberían seguir unas directrices generales como:

a. Rotular aquellas imágenes que puedan provocar confusión al espectador y que le lleve a no entender lo que está viendo.

b. Si una imagen noticia no es rotulada, el off deberá proporcionar la información necesaria. Si no, deberá ser rotulada para que no pierda su valor informativo.

c. Se deberían rotular las secuencias de películas. El espectador puede no saber a qué película pertenece la secuencia utilizada.

d. Se deben rotular las "imágenes ficticias" (secuencias de películas utilizadas para ilustrar un acontecimiento real o la vida de un personalidad) para que al telespectador no le quede ninguna duda de que lo está viendo es una recreación del acontecimiento.

e. Se deberían rotular las imágenes noticia (tanto lejana como reciente) que sean confundidas como imágenes grabadas ex profeso para dicho reportaje, especialmente si son declaraciones o fragmentos de entrevistas.

\section{BIBLIOGRAFÍA}

AGIRREAZALDEGI BERRIOZABAL, Teresa. El uso de la Documentación audiovisual en los programas informativos diarios. Bilbao, Universidad del País Vasco, 1996.

BANDRÉS, Elena et al. El periodismo en la televisión digital. Barcelona, Paidós, 2000.

BARROSO GARCÍA, Jaime. "Reportajes y nueva televisión. No hay sitio, ni tiempo, ni dinero “. Caleidoscopio. Valencia, Universidad Cardenal Herrera CEU n⿳ 5, 2002.

DIAZ ARIAS, Rafael. Periodismo en televisión. Entre el espectáculo y el testimonio de la realidad. Barcelona, Editorial Bosch, 2006.

FERRO, Marc. Historia contemporánea y cine. Barcelona, Ariel Historia, 1995.

GARCIA NEBRADA, Begoña, MENOR SENDRA, Juan y PERALES ALBERT, Alejandro, VIDAL. Telediarios y producción de la realidad. Madrid, RTVE, 1985, 2 vol.

MAGRO, Baltasar. Informe Semanal. 30 años. Barcelona, Plaza y Janés, 2003

PHILLIPPE, Virginie. Transition et televisión en Espagne. Le rôle de la TVE. 19731978. París, L'Harmattan, 2007. 


\section{$\underline{\text { Reportajes de Informe Semanal incluidos en la muestra de estudio }}$}

- 03/01/2009: Guerra en la Franja de Gaza.

- 03/01/2009: Una isla en la corriente.

- 03/01/2009 Mujeres del vino.

- 03/01/2009: Labordeta, de frente.

- 10/01/2009 Atrapados en la nieve.

- 10/01/2009 El martirio de Gaza.

- 10/01/2009 Ribadelago, la memoria sumergida

- 10/01/2009 Alarma en la locomotora europea.

- 17/01/2009 Vacuna Made in Spain.

- 17/01/2009 Esperando a Obama.

- 17/01/2009 La guerra fría del gas.

- 17/01/2009 Cerco al hermano lobo.

- 24/01/2009 Viento mortal.

- 24/01/2009 El banquero de los pobres.

- 24/01/2009 Presidente Obama.

- 24/01/2009 Madrid Fusión.

- 31/01/2009 La crisis de los pequeños.

- 31/01/2009 Valkiria, objetivo matar a Hitler.

- 31/01/2009 ¿Viaja Dios en autobús?

- 31/01/2009 Las favoritas de los Goya

- 07/02/2009 Sin noticias de Marta.

- 07/02/2009 Politkovskaya, la sombra de un juicio.

- 07/02/2009 Ciudadanos sin objeción.

- 07/02/2009 Bacon, la mirada oblicua

- 14/02/2009 Tormenta política sobre Madrid

- 14/02/2009 Irán: Las fronteras de la revolución

- 14/02/2009 Menores en riesgo

- 14/02/2009 La hora de Eulana

- 21/02/2009 El rastro de Marta

- 21/02/2009 La rebelión de los jueces

- 21/02/2009 Nuremberg asiático.

- 21/02/2009 Darwin ¿De dónde venimos?

- 28/02/2009 El oscar de "Pe".

- 28/02/2009 Bolonia, el conocimiento único

- 28/02/2009 La pasión según Almodóvar.

- 07/03/2009 1-M: Nuevo tiempo político.

- 07/03/2009 La cesta blanca.

- 07/03/2009 Yihad.es

- 14/03/2009 La segunda vida de Andrés.

- 14/03/2009 El Ulster, la paz amenazada.

- 14/03/2009 Tibet, medio siglo de ocupación.

- 14/03/2009 El dinero rojo. 
- 21/03/2009 Decidir a los 16

- 21/03/2009 20 años de impunidad.

- 21/03/2009 Chad, un futuro incierto

- 21/03/2009 La memoria de la tierra

- 04/04/2009 Nuevo mundo, nuevas reglas.

- 04/04/2009 Ciudades con conciencia verde

- 04/04/2009 Entre la miseria y la guerra

- 04/04/2009 El regreso de un mito

- 18/04/2009 Elena Salgado, la cartera de la crisis

- 18/04/2009 La vuelta de "Pepe el del Popular"

- 18/04/2009 Los últimos de Guantánamo

- 18/04/2009 Dioses, tumbas y sabios

- 25/04/2009 El rostro del paro

- 28/04/2009 Yak-42, 6 años en la tiniebla

- 28/04/2009 Pigmeos, los nómadas de la selva

- 28/04/2009 Tierra de peregrinos

\section{Otros reportajes consultados}

- Informe Semanal, no 1067. "Guantánamo, la cárcel de la vergüenza". Emitido el 12 de enero de 2008.

- Informe Semanal: La otra historia del Yak 42" emitido el 29 de junio de 2008.

- Informe Semanal. $n^{\circ}$ 1108. "Más que hermanos" Emitido el 29 de noviembre de 2008.

\section{Otras fuentes audiovisuales consultadas}

- Sólo contra Hitler (Allein gegen den Fuhrer). Dirigido por Rudiger Liedtke. Alemania, WDR, 1989.

- El ejército de los pobres. Dirigido por Jorge Iglesias. España, News Atlantis, 2002.

- Reportaje de En Portada. "Utopía y terror Los jemeres rojos". Reportaje elaborado por Vicente Romero y realizado por J. Carlos Ribas.. Emitido el 7 de marzo de 2005. 